Available online at: http://proceeding.rsfpress.com/index.php/ic-smart/index

Proceeding on International Conference of Science Management Art Research Technology

(IC-SMART)

Volume 1 Number 1 (2020): 101-116

\title{
Constituents Driving Interest in Using E-Wallets in Generation Z
}

\author{
Fitria Halim $^{1}$, Efendi ${ }^{1}$, Marisi Butarbutar ${ }^{1}$, Anne Rumondang Malau ${ }^{2}$, Acai \\ Sudirman ${ }^{1}$ \\ ${ }^{1}$ Management Study Program, Sekolah Tinggi Ilmu Ekomomi Sultan Agung, Indonesia; \\ ${ }^{2}$ Management Study Program, Universitas HKBP Nommensen, Indonesia \\ E-mail address fitriahalim2839@stiesultanagung.ac.id, E-mail address \\ efendi@stiesultanagung.ac.id,E-mail address marisibutarbutar@stiesultanagung.ac.id,.E- \\ mail address anne.malau@uhn.ac.id,E-mail address acaivenly@stiesultanagung.ac.id
}

\begin{abstract}
Nowadays, the use of information technology is increasingly prevalent so that it has a direct impact on lifestyle changes of people who want everything in fast and instantaneous ways, in which one of them occurs in the financial sector. Following the people's needs, various electronic payment instruments called E-Wallets have emerged. In the phenomenon of the use of this new technology, there are undoubtedly many factors that are indicated to influence it. The objective of this study is to find out the behavior of Generation $Z$ in using E-Wallet by applying the UTAUT (Unified Theory of Acceptance and Use of Technology) theory model. This study used quantitative data in the form of an exploratory survey using an online questionnaire. Using the PLS-SEM method and non-probability sampling research techniques with a purposive sampling method, it obtained a sample of the study of 146 respondents. The results showed that the Perceived Ease of Use, Facility Condition, and Social Influence had a significant effect on the behavior of using EWallet. Meanwhile, Perceived Usefulness had no effect on interest in using E-Wallet.
\end{abstract}

Keywords: perceived ease of use, perceived usefulness, facility condition, social influence, generation Z

This is an open access article under the $\mathrm{CC}-\mathrm{BY}-\mathrm{NC}$ license

\section{INTRODUCTION}

The current development and acceleration of information technology innovation have emerged as a stimulus to facilitate users of commercial transactions in their daily lives (Keng-Soon et al. 2019). Innovations in the field of financial technology have helped business organizations design a more exclusive financial transaction model oriented towards fulfilling customer needs (Salmony, 2014). This can be proved from the aspect of increasing the consumption of banking services, which is increasing every year following innovations in the financial sector. This assumption is then embedded in non-cash transactions to prove that consumption is one of the factors in strengthening the class advantage of society and maintaining group relations (Welly et al. 2020). The implication of the rapid development of information technology on mobile devices has had an impact on 
increasing Fintech users with easy payments in the form of digital wallets. E-Wallet, as one of the most innovative and recent technologies, becomes an excellent example of mobile banking as a revolution in the finance field that can render financial transactions for clients to carry out independently. (Alalwan, Dwivedi, and Rana 2017). E-Wallet is an application that facilitates users to make payments via mobile devices without involving financial transactions in the form of cash (Intarot and Beokhaimook 2018). This new technology is expected to provide convenience and ease of transactions for users and provide advantages for customers (Badri 2020). The emergence of this financial application innovation also supports non-cash transactions, which function as electronic money. The providers that are now widely used in Indonesia are, for example, Link Aja, Ovo, Gopay, DANA, e-toll, YAP, Sakuku, etc. Besides, there is also uNIK, which is a mobile social banking application that provides server-based electronic money services and the laku pandai service (Bank Indonesia, 2019). In a study by (Bagla and Sancheti 2018), it is stated that the emergence of financial updates is due to technological factors that are increasingly developing, and the implications of developments in the non-cash financial transaction sector are expected to drive an increase in the value of financial transactions carried out by the society. The convergence of the development of wireless telecommunications with the support of multi-functional mobile has led to changes in conducting financial transactions with a more flexible method than using cash or ATM cards (Sunny 2018).

Furthermore, the implications of the rapid development of information technology and the use of electronic money have had an impact on lifestyle changes in the society due to the demands of a fastpaced life (Fitria and Winata 2020). A previous study that explains the adoption of digital wallets or what is known as E-Wallet has previously been carried out (Houston 2020) on the millennial generation in Jakarta, in which the findings state that the use of digital payment applications is quite well accepted by the millennial generation because of the new innovations provided by several EWallet platforms. Moreover, a study by (Kesumastuti 2020) found that the millennial generation in Jakarta is interested in adopting the Go-Pay application because of its benefits and ease of use. A study by (Purwanto, Hartini, and Premananto 2019) on the millennial generation found that perceptions of usefulness, ease, enjoyment, and passion have a positive effect on attitudes and intentions to use Go-Pay. Further, the application of digital wallets is also studied by (Badri 2020), who found that Generations $\mathrm{Y}$ and $\mathrm{Z}$ in Pekanbaru City are very active users of digital wallets. Furthermore, the findings found that the reason that Generations $\mathrm{Y}$ and $\mathrm{Z}$ in Pekanbaru City use digital wallets is because of the advantages of using them, which are very suitable for the needs of non-cash transactions.

This study was conducted on the basis of several unsolved problems regarding factors that drive Generation $\mathrm{Z}$ to use E-Wallet, and other reasons why this study was conducted are because this study is the first to be conducted in Pematangsiantar City, North Sumatera, Indonesia. The research problems are the use of E-Wallet that is not yet optimal as an instrument for carrying out non-cash transactions and the factors that drive the readiness of Generation $\mathrm{Z}$ as part of the Cashless Society to use E-Wallet that has not been determined (Rif'ah 2019). Therefore, by conducting this study, it is expected that the factors that can drive the readiness of Generation $Z$ to use E-Wallet as part of a cashless society in the era of the industrial revolution 4.0 in the future will be determined. This study aims to find out the factors that drive Generation $\mathrm{Z}$ to use E-Wallet in Pematangsiantar City.

\section{LITERATURE REVIEW}

E-Wallet

The development of the increasingly advanced internet world encourages the use of electronic wallets as a more efficient means of transactions than using banks. This is proved by the number of e- 
commerce websites that use electronic wallets as a means of transaction. E-Wallet is a wallet that is connected to a server in the form of a smartphone application that allows the users to save a certain amount of money to be used anytime and anywhere as long as the payment service is available properly (Bagla and Sancheti 2018). Electronic wallets are first recognized as a method for saving money in electronic form, but they become popular because they are suitable for providing a convenient transaction alternative for internet users to store and use the information on online shopping (Chawla and Joshi 2019).E-Wallet makes transactions easier because the users do not need to carry large amounts of cash. Only by having a deposit in an E-Wallet that is installed on a smartphone with internet network payments can be made easily or known as cashless transactions. One of the payment methods using E-Wallet can be carried out by scanning a barcode or commonly called a QR code. Indicators in assessing transactions that have successfully used an E-Wallet can be seen from the successful activation of the E-Wallet in the transaction process after verifying or scanning the user's barcode at the merchant with E-Wallet providers (Singh, Sinha, and LiébanaCabanillas 2020).

\section{UTAUT Model}

In the last few decades, UTAUT has been applied in various sectors of the company to study various uses of organizational strengthening technology. As technology is increasingly used for individual use, UTAUT settings have been adapted to meet these requirements by adding additional constructs: hedonic motivation, habit, price value, and perceived enjoyment (C. Kim, Li, and Kim 2015). Unified Theory of Acceptance (UTAUT) is a model used to explain users' interest in their usage behavior. The UTAUT model is built by four constructs, including the performance expectation, job expectation, social influence (SI), and facility conditions. It can be considered that UTAUT is a renewal model of TAM, which is used to explain how the acceptance and adoption of technology can change people's behavior patterns (Venkatesh et al. 2016).In a study on the adoption of technology, the TAM and UTAUT models are commonly used simultaneously or only one of them. Related variables such as social influence, security, and facility condition are also commonly added to measure the behavior of technology adoption. Related studies using the TAM and UTAUT models include studies by (Beheshti, Benatallah, and Motahari-Nezhad 2018) on mobile banking, electronic money (Anjelina, 2018; Priambodo \& Prabawani, 2016), digital payments (Nidhi Singh, Shalini Srivastava 2017).

\section{Generation Z}

Generation $\mathrm{Z}$ is a generation that was born when technology was developing at a fast pace. One of the characteristics of this generation is that they are very familiar with various kinds of technology from birth. Generation $\mathrm{Z}$ has the characteristic of liking all instantaneous things, highly dependent on technology and liking entrepreneurial works (Howe \& Nadler, 2012). Those who belong to Generation $\mathrm{Z}$ are born when a lot of new technology is being discovered and developed so that they do not learn and adopt the new technology that is available. Born when the technology era grows faster, it definitely has an impact on this generation. For example, Generation Z becomes very dependent on anything related to technology. One example that Generation $Z$ depends on technology is that they are very familiar with smartphones and internet networks in their everyday life. Generation Z's dependence on smartphones has led to new social phenomena that occur among them, such as greater anti-social attitudes, easy feelings of loneliness, and addiction to gadgets and online games (Howe \& Nadler, 2012).

\section{Behavioral Intention}

Some literature studies explain that the behavior that drives a person to use new technology is largely due to its strong role in shaping the actual experience of use (Venkatesh et al. 2016). According to (Abrahão, Moriguchi, and Andrade 2016), behavioral intention is used to study the orientation of an individual's behavior to adopt new technology. (Fitria and Winata 2020)said that behavioral intention 
shows how hard an individual tries to commit to a behavior. The intensity of high commitment reflects the realization of strong behavior. Furthermore (Gu, Lee, and Suh 2009), stated that behavioral intention to use reflects the condition of an individual to perform the behavior on the basis of a willingness to try and be motivated to do so. Higher-intentioned clients of adopting emerging technology are more likely to be adopters and will promote it to others (Lancelot Miltgen, Popovič, and Oliveira 2013).

\section{Perceived Ease of Use}

One of the two primary constructs that form the TAM model is Perceived Ease of Use. Perceived Ease of Use is described as an easy-to-learn and easy-to-use system by the users or known as user friendly (Chawla and Joshi 2019). The idea of easy-to-use is also said by Alsamydai et al. (2014), in which it is described as the behavior to use technology-based financial transactions to avoid issues occurring caused by technology. The findings of a previous study conducted by Welly et al. (2020) emphasized the positive relationship between perceived user-friendliness and intention to utilize mobile banking in Thailand. The same results were reported by Bagla and Sancheti's (2018) research analyzing the gap satisfaction in electronic wallets in India, stating that Perceived Ease of Use had a positive and significant effect on behavior to utilize Fintech. Subsequently, preliminary research in Malaysia carried out by Huei et al. (2018) on FinTech showed that the factor of ease of use has been effective in influencing consumer behavior to utilize products and services of FinTech.

Perceived Usefulness

Perceived Usefulness (PU) is a construct in the TAM model, which is defined as a feeling that consumers perceive when adopting a new finding that the technology used can help ease their work or tasks in everyday life (Chen, Chen, \& Kazman, 2007). In other words, this condition leads to a consumer performance perspective regarding the results of the experience after perceiving the benefits of adopting new technology (Wonglimpiyarat 2017). (Moslehpour et al. 2018), investigated the decision of online shopping by Taiwanese consumers based on the usability after using E-Wallet payments so that this could be a predictor of consumers' intention to adopt FinTech in fulfilling their financial transaction needs. As stated by (Huei et al. 2018) on the adoption of mobile banking in India, and (Lavenia, Iqbal, and Irawan 2018) on the adoption of mobile banking in Iran, they stated that the feeling of usefulness perceived by consumers would determine the behavior of its users in adopting the technology.

\section{Social Influence}

Social influence in the context of digital wallets can be defined as the encouragement or influence of external factors that are the reason why an individual becomes a digital wallet user. The social environment affects the adoption of new technology ( $\mathrm{Lu}, \mathrm{Yao}, \& \mathrm{Yu}, 2005)$. Social influence consists of various types, such as the influence of relatives or family, friend recommendations, the surrounding environment, advertisements, user testimonials, etc. According to ( $\mathrm{Lu}, \mathrm{Yao}, \& \mathrm{Yu}$, 2005), which examined wireless internet services in mobile technology, it states that the use of technology by people in the surrounding environment affects individual decisions to also use wireless internet services in mobile technology. Still about social influence, (Singh, Sinha, and LiébanaCabanillas 2020) also mentioned that the good experience of using a mobile wallet by an individual would make them feel free to also recommend people around them to use a mobile wallet. One of the two primary constructs that form the TAM model is Perceived Ease of Use. Perceived Ease of Use is described as an easy-to-learn and easy-to-use system by the users or known as user friendly (Chawla and Joshi 2019). The idea of easy-to-use is also said by Alsamydai et al. (2014), in which it is described as the behavior to use technology-based financial transactions to avoid issues occurring caused by technology. The findings of a previous study conducted by Welly et al. (2020) emphasized 
the positive relationship between perceived user-friendliness and intention to utilize mobile banking in Thailand. The same results were reported by Bagla and Sancheti's (2018) research analyzing the gap satisfaction in electronic wallets in India, stating that Perceived Ease of Use had a positive and significant effect on behavior to utilize Fintech. Subsequently, preliminary research in Malaysia carried out by Huei et al. (2018)on FinTech showed that the factor of ease of use has been effective in influencing consumer behavior to utilize products and services of FinTech (Chuang et al. 2016). A study by (Keng-Soon et al. 2019) confirmed that an individual tends to be more alert to use a new system because of a feeling of uncertainty, so that accurate information from the social environment is needed to make decisions regarding the use.

Facility Condition

Many developing countries, including India, are committed to supporting the smooth running of financial transactions in society. Thus, attention is needed to focus on conditions of more efficient and transparent online transaction facilities (Kumar, Adlakaha, and Mukherjee 2018). Facility Condition can be stated as the user's feeling of trust in the existence of service units provided by service providers for supporting facilities such as technical infrastructure, knowledge of usage, and consumer assistance services (Madan and Yadav 2016). In the current situation of technological development, the fact shows that online-based new technology service providers require certain types of skills, resources, and technical infrastructure to support the smooth use of non-cash financial transactions (Alalwan, Dwivedi, and Williams 2016). In a study on mobile wallet conducted by (Chawla and Joshi 2019), the facility condition such as knowledge of the use of the individual user, availability of electronic money payment services, suitable devices for accessing digital wallets, internet networks, and consumer services, affect the behavior of mobile wallet adoption in India.

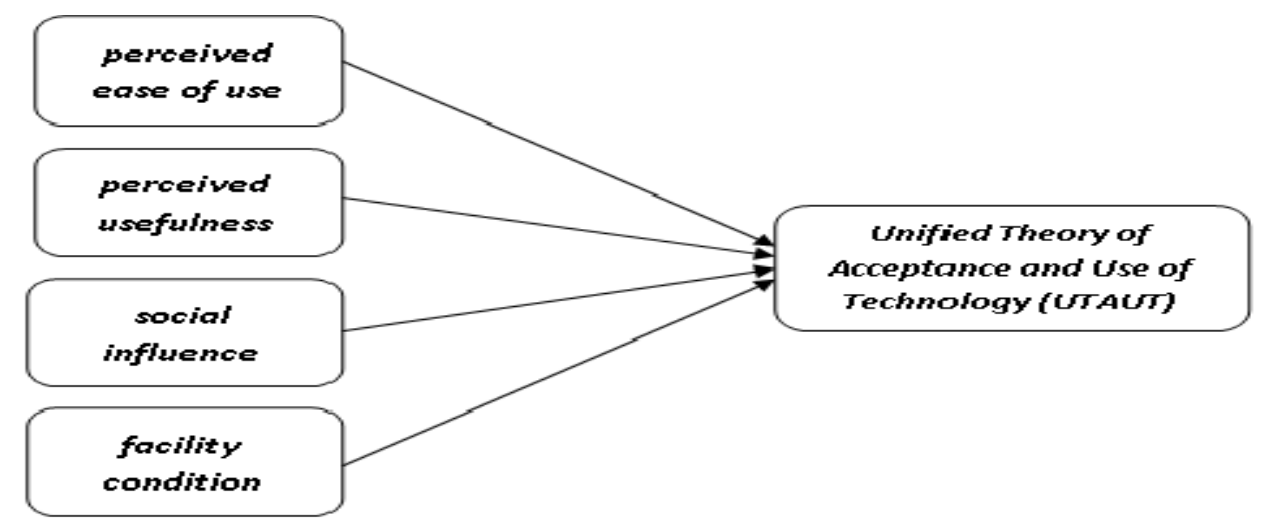

Figure 1. Research Framework

Hypothesis Testing

Based on the background of the problem and the framework that has been previously explained, the hypotheses formulated in this study are as follows:

Hypothesis 1: Perceived ease of use affects behavioral intention

Hypothesis 2: Perceived usefulness affects behavioral intention

Hypothesis 1: Social influence affects behavioral intention

Hypothesis 2: Facility condition affects behavioral intention 


\section{RESEARCH METHODOLOGY}

In this study, the researchers used quantitative methods with an exploratory survey approach. To obtain suitable data, the researchers used indicators to represent each research variable. The data sources used in the study were from primary data and secondary data. The primary data were obtained from a survey through a questionnaire distributed online. All data obtained for this study were from questionnaires distributed online in the Google Form link. Meanwhile, the secondary data were indirect data obtained from the results that have been collected before. The population of this study was all Generation Z of E-Wallet users who are active in Pematangsiantar City. Unfortunately, there was no exact data that stated the number of active E-Wallet users in Pematangsiantar City. This is caused by several factors, such as one person can have more than one active E-Wallet, and there is no information regarding the exact number report from the E-Wallet provider regarding its users. Thus, the researchers determined the number of samples that were considered sufficient to represent the population of E-Wallet users in Pematangsiantar City. This study selected a sample with nonprobability sampling with the purposive sampling type. The consideration of choosing this nonprobability purposive sampling is because there are no numbers that explain the number of the population. Some of the criteria set by the researchers, including that the sample already has an account on E-Wallet and has been actively using it for at least one month. The estimate and hypotheses are testing from the research model using the Partial Least Square Structural Equation Model (PLS-SEM). This method was chosen because it is suitable for a research model that is developing a theory or that is called an exploratory model. This is because, in research with PLSSEM, all data are assumed to have been normally distributed. Another reason why this study chose the PLS-SEM method is that this method is proved to be good for testing on small-scale data or the exploratory research (Hair, 2014). Furthermore, the measurement of the research variable indicators used question items summarized in the form of an online questionnaire which can be explained in Table 1 below:

Table 1. Measurement of Research Variables

\begin{tabular}{|c|c|c|c|}
\hline Variable & Code & Item & Reference \\
\hline \multirow{4}{*}{$\begin{array}{l}\text { Perceived } \\
\text { ease of use }\end{array}$} & PEU1 & Easy to learn & \multirow{4}{*}{$\begin{array}{l}\text { (Chawla and Joshi } \\
\text { 2019) }\end{array}$} \\
\hline & PEU2 & Easy to understand & \\
\hline & PEU3 & Easy to effortless & \\
\hline & PEU4 & Easy to use & \\
\hline \multirow{4}{*}{$\begin{array}{l}\text { Perceived } \\
\text { usefulness }\end{array}$} & PUS1 & Useful in my daily life & \multirow{4}{*}{$\begin{array}{c}\text { Samudra \& Phadtare } \\
\text { (2012) }\end{array}$} \\
\hline & PUS2 & Very helpful & \\
\hline & PUS3 & Accomplish tasks more efficiently & \\
\hline & PUS4 & Becomes easier after using & \\
\hline \multirow{3}{*}{$\begin{array}{r}\text { Social } \\
\text { influence }\end{array}$} & SI1 & Referred by my family & \multirow{3}{*}{$\begin{array}{l}\text { (Singh, Sinha, and } \\
\text { Liébana-Cabanillas } \\
\text { 2020) }\end{array}$} \\
\hline & SI2 & Referred by my friends & \\
\hline & SI3 & Referred by people in society & \\
\hline Facility & FC1 & Appropriate for using & \\
\hline condition & $\mathrm{FC} 2$ & Cost of purchasing & \\
\hline
\end{tabular}


Proceeding on International Conference of Science Management Art Research Technology (IC-SMART),

$$
\text { Vol. } 1 \text { (1), 101-116 }
$$

Constituents Driving Interest in Using E-Wallets in Generation Z

Fitria Halim, Efendi, Marisi Butarbutar, Anne Rumondang Malau, Acai Sudirman

\begin{tabular}{|c|c|c|c|} 
& FC3 & $\begin{array}{c}\text { Knowledge necessary to use } \\
\text { Can easily find a person }\end{array}$ & $\begin{array}{c}\text { (Venkatesh et al. } \\
\text { FC4 }\end{array}$ \\
\cline { 4 - 4 } Behavioral & BI1 & Performance expectancy & (Chawla and Joshi \\
intention & BI2 & Effort expectancy & 2019) \\
& BI3 & Social influence & \\
& BI4 & Facilitating conditions & \\
\hline
\end{tabular}

Source: Processed previous references (2020)

\section{FINDING AND DISCUSSION}

Results of the Study

The questionnaire was distributed online via social media of WhatsApp and Telegram. Social media was chosen because many of the target respondents are actively using social media in their daily lives. Of the 192 responses received, only 146 data (76.04\%) were considered valid for the study. The characteristics of the respondents required in this study include samples who have an account on E-Wallet and have been actively using it for at least one month. The characteristics of respondents in this study will be described in Table 2 and Table 3, which consist of general profiles of the respondents and general information regarding the use of E-Wallet.

Table 2. General Profile of the Respondents

\begin{tabular}{cccc}
\hline Category & Details & Number & Percentage \\
\hline \multirow{2}{*}{ Sex } & Male & 61 & $41.78 \%$ \\
& Female & 85 & $58.22 \%$ \\
\multirow{3}{*}{ Age } & $14-16$ years old & 10 & $4.21 \%$ \\
& $17-19$ years old & 18 & $33.72 \%$ \\
& 20-22 years old & 52 & $51.05 \%$ \\
& 23-25 years old & 66 & $11 \%$ \\
& Students & 14 & $10.77 \%$ \\
Occupation & College Students & 35 & $74.2 \%$ \\
& Employees & 72 & $11.7 \%$ \\
& Entrepreneurs & 16 & $1.4 \%$ \\
& Others & 9 & $1.85 \%$ \\
\hline
\end{tabular}

Source: Processed Data (2020)

Table 3.Informationof the Use of E-Wallet of the Respondents

\begin{tabular}{cccc}
\hline Category & Details & Number & Percentage \\
\hline Frequently used & GOPAY & 54 & $36.99 \%$ \\
E-Wallet & OVO & 37 & $25.34 \%$ \\
& DANA & 18 & $12.33 \%$ \\
\hline
\end{tabular}


Proceeding on International Conference of Science Management Art Research Technology (IC-SMART),

Vol. 1 (1), 101-116

Constituents Driving Interest in Using E-Wallets in Generation Z

Fitria Halim, Efendi, Marisi Butarbutar, Anne Rumondang Malau, Acai Sudirman

\begin{tabular}{cccc}
\hline & PayTren & 3 & $2.05 \%$ \\
LinkAja & 4 & $2.74 \%$ \\
Shopeepay & 30 & $20.55 \%$ \\
More than 3 months & 57 & $39.04 \%$ \\
& More than 6 months & 44 & $30.14 \%$ \\
More than 1 year & 30 & $20.55 \%$ \\
Intensity of use per & More than 2 years & 15 & $10.27 \%$ \\
month & $1-3$ times & 68 & $46.58 \%$ \\
& 3- 5 times & 32 & $21.92 \%$ \\
& 5-10 times & 29 & $19.86 \%$ \\
Purpose of using E- & More than 10 times & 17 & $11.64 \%$ \\
Wallet & Online transportation & 41 & $28.08 \%$ \\
& Onlinefood order & 27 & $18.49 \%$ \\
& Transfer of money & 12 & $8.22 \%$ \\
& Purchase credit vouchers & 7 & $4.79 \%$ \\
& Payment at shops/merchants & 18 & $12.33 \%$ \\
& Online shop payment & 26 & $17.81 \%$ \\
& Credit/cinema ticket payments & 4 & $2.74 \%$ \\
& Payment of electricity/water bills & 11 & $7.54 \%$ \\
& $<$ IDR 500.000 & 83 & $56.85 \%$ \\
& IDR500,000 - IDR1,000,000 & 32 & $21.92 \%$ \\
& IDR1,000,000 - IDR1,500,000 & 17 & $11.64 \%$ \\
& IDR1,500,000 - IDR2,000,000 & 10 & $6.85 \%$ \\
& $>$ IDR2,000,000 & 4 & $2.74 \%$ \\
\hline
\end{tabular}

Source: Processed Data (2020)

Outler Model Measurement

The results of the data obtained from the research questionnaire were processed using the SmartPLS version 3.2.8 application with processing guidelines by Juliandi (2018). In measuring the outer model, the tests conducted are the validity test and reliability test. A convergent validity test is determined by the loading factor and AVE with the condition that the loading factor is above 0.7 , and the AVE value is 0.5 (Hair et al., 2014). The model reliability test, according to Hair et al. (2014), is seen from the value of Cronbach's alpha and composite reliability (CR), which has a value higher than 0.7. Based on Figure 1 and Table 4, and Table 5 below, it can be concluded that the value of each measuring instrument used in this study is valid and reliable. 


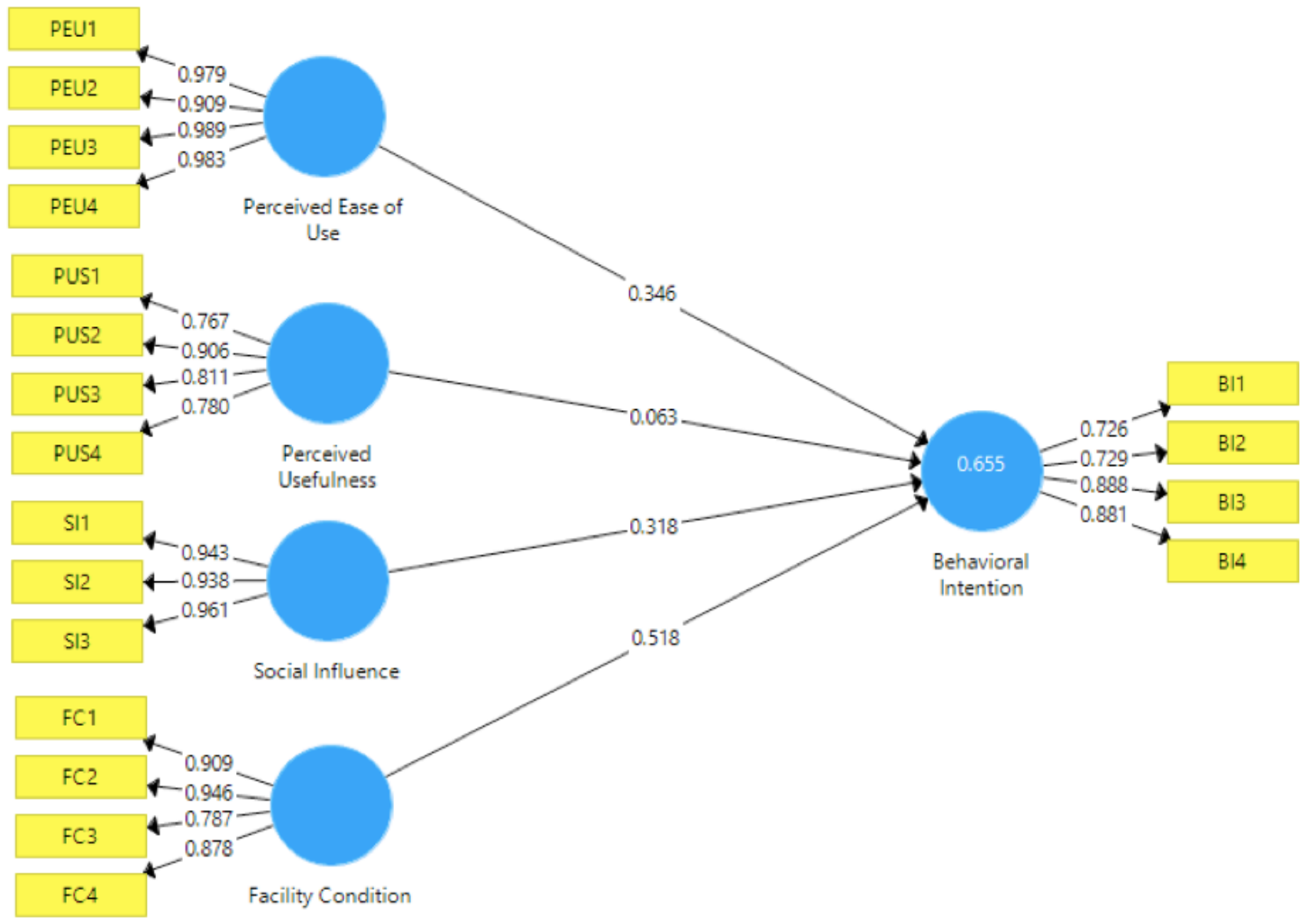

Figure 2. Outler Model Display

Table 4. Outler Model Measurement Results

\begin{tabular}{|l|r|r|r|}
\hline Notes & Cronbach's Alpha & $\begin{array}{l}\text { Composite } \\
\text { Reliability }\end{array}$ & $\begin{array}{c}\text { Average Variance } \\
\text { Extracted (AVE) }\end{array}$ \\
\hline Perceived Ease of Use & 0.975 & 0.982 & 0.932 \\
\hline Perceived Usefulness & 0.844 & 0.889 & 0.669 \\
\hline Social Influence & 0.943 & 0.963 & 0.897 \\
\hline Facility Condition & 0.903 & 0.933 & 0.778 \\
\hline Behavioral Intention & 0.824 & 0.883 & 0.656 \\
\hline
\end{tabular}

Source: Processed Data (2020)

Table 5. Loading Factor Results

\begin{tabular}{|c|r|r|r|r|c|}
\hline Notes & $\begin{array}{c}\text { Perceived } \\
\text { Ease of Use }\end{array}$ & $\begin{array}{c}\text { Perceived } \\
\text { Usefulness }\end{array}$ & $\begin{array}{c}\text { Social } \\
\text { Influence }\end{array}$ & $\begin{array}{c}\text { Facility } \\
\text { Condition }\end{array}$ & $\begin{array}{c}\text { Behavioral } \\
\text { Intention }\end{array}$ \\
\hline PEU1 & 0.979 & & & & \\
\hline PEU2 & 0.909 & & & & \\
\hline PEU3 & 0.989 & & & & \\
\hline PEU4 & 0.983 & & & & \\
\hline PUS1 & & 0.767 & & & \\
\hline PUS2 & & 0.906 & & & \\
\hline
\end{tabular}


Proceeding on International Conference of Science Management Art Research Technology (IC-SMART),

Vol. 1 (1), 101-116

Constituents Driving Interest in Using E-Wallets in Generation Z

Fitria Halim, Efendi, Marisi Butarbutar, Anne Rumondang Malau, Acai Sudirman

\begin{tabular}{|l|l|l|l|l|l|}
\hline PUS3 & & 0.811 & & & \\
\hline PUS4 & & 0.780 & & & \\
\hline SI1 & & & 0.943 & & \\
\hline SI2 & & & 0.938 & & \\
\hline SI3 & & & 0.961 & & \\
\hline FC1 & & & 0.909 & \\
\hline FC2 & & & & 0.946 & \\
\hline FC3 & & & & 0.787 & \\
\hline FC4 & & & & 0.878 & 0.726 \\
\hline BI1 & & & & & 0.729 \\
\hline BI2 & & & & & 0.888 \\
\hline BI3 & & & & & \\
\hline BI4 & & & & & \\
\hline
\end{tabular}

Source: Processed Data (2020)

In the validity test presented in Table 4 and Table 5 above, the value of each loading factor and AVE on the variable indicator for perceived ease of use, perceived usefulness, social influence, facility condition, and behavioral intention is above 0.7 for loading factor and above 0.5 for AVE. Moreover, the value for each reliability above obtained the composite reliability value of above 0.7 for each research variable, which can be explained as follows: perceived ease of use obtained 0.982 , perceived usefulness obtained 0.889 , social influence obtained 0.963 , facility condition obtained 0.933 , and behavioral intention obtained 0.883 . Furthermore, for the Cronbach's alpha value, the value for each variable is above 0.60 , which shows that all research variables have good reliability values. With these good values, it can be used as an overview that the condition of the relationship between variables is also good so that further tests can be carried out.

Inner Model Measurement

Inner model measurement is carried out by bootstrapping research data using SmartPLS version 3.2.8. There are two results obtained from the bootstrapping, including the significance of the two related variables and the R-square of the study. The value of the R-square is the value that shows the ability of exogenous variables to build endogenous variables. According to Chin (1998), there are three categories of R-square values, in which if the R-square value is 0.19 , the relationship between exogenous variables forming an endogenous variable is weak, if it is 0.33 , it means that the relationship is moderate, and if the value is 0.67 , it means that the connection is strong. Meanwhile, Sarwono (2016) stated that if the R-square value is more than 0.67 , the relationship between endogenous and exogenous variables is very strong.

Table 6. Calculation Results of the R-Square Value

\begin{tabular}{|l|l|l|}
\hline Notes & R Square & R Square Adjusted \\
\hline Behavioral Intention & 0.655 & 0.645 \\
\hline
\end{tabular}

Source: Processed Data (2020)

Seen from the R-square value of each endogenous variable, the value ranges from 0.33 to 0.67 . This shows that, overall, the ability of the exogenous variables to explain endogenous variables is moderate. Further, to prove the hypothesis testing, a significance test is carried out to determine the 
relationship between the exogenous variables and endogenous variables. The criterion of significance is seen from the p-value. With a significance level of $5 \%$, if the p-value between the exogenous and endogenous variables is lower than 0.05 , it means that the exogenous variable has a significant effect on the endogenous variable. On the contrary, if the value is higher than 0.05 , it means that the exogenous variable does not have a significant effect in formulating the endogenous variable.

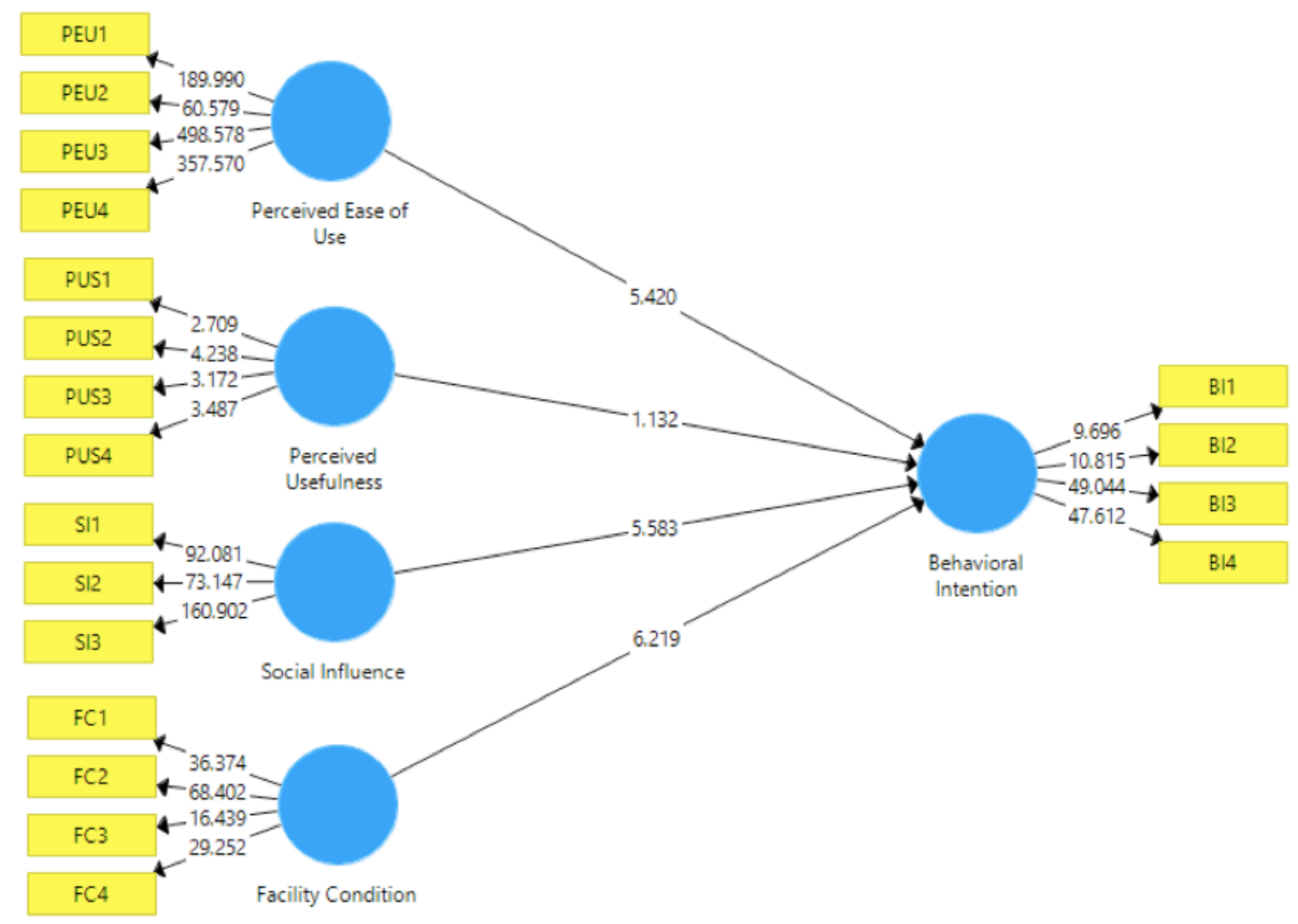

Figure 3. Inner Model Display

Table 7. Path Coefficients Test Results

\begin{tabular}{|c|c|c|c|c|}
\hline Path Between Variables & Coefficient & $\begin{array}{c}\mathrm{t}- \\
\text { count }\end{array}$ & $\begin{array}{c}\text { P- } \\
\text { Value }\end{array}$ & Conclusions \\
\hline $\begin{array}{c}\text { Perceived ease of use } \\
>>\text { Behavioral intention }\end{array}$ & 0.346 & 5.420 & 0.000 & Significant \\
\hline $\begin{array}{c}\text { Perceived usefulness } \\
>>\text { Behavioral intention }\end{array}$ & 0.063 & 1.132 & 0.258 & NotSignificant \\
\hline $\begin{array}{c}\text { Social influence } \\
\text { > Behavioral intention }\end{array}$ & 0.318 & 6.937 & 0.000 & Significant \\
\hline $\begin{array}{c}\text { Facility condition } \\
>>\text { Behavioral intention }\end{array}$ & 0.518 & 6.219 & 0.002 & Significant \\
\hline
\end{tabular}

Source: Processed Data (2020)

Based on the results of the processed data presented in Table 7 above, the significance test of the direct relationship between exogenous and endogenous variables can be considered that overall exogenous variables have a significant effect on endogenous variables, even though there is one 
exogenous variable that does not affect the endogenous variable. Of the four hypotheses formulated, 1 hypothesis is rejected, which is for the effect of the Perceived Usefulness variable on the Behavioral Intention variable, which does not have a significant effect. While the variables of Perceived Ease of Use, Social Influence, and Facility Condition have a significant effect on Behavioral intention.

\section{Discussion}

The Effect of Perceived Ease of Use on Behavioral Intention

The results of the study show that perceived ease of use has a positive and significant effect on interest in using E-Wallet. This shows that the feeling of ease in using E-Wallet not only affects their usage habits but also affects the feelings of trust from users, so the implications of these feelings drive behavior to reuse the product. The results of this study are in line with several previous studies, in which, in related studies, it was concluded that the existence of an easy system affects the habits that drive its use (Sharma et al. 2018) \& (Nidhi Singh, Shalini Srivastava 2017). Further, studies by (Mehra, Paul, and Kaurav 2020) \& (Wong and Mo 2019) showed that the aspect of ease has a positive and significant effect on interest in using E-Wallet services. These results reflect the situation before deciding to adopt the use of E-Wallet. The users, in this case, Generation Z, evaluate the use of noncash payment transactions using cell phones to obtain a concrete overview of the ease of use of EWallet in the long term. On the other hand, the results of this study contradict a study by Setiani (2018), which stated that perception of ease does not have a significant effect on the use of non-cash payment instruments. Some users who are still not familiar with the ease provided by the E-Wallet service think that the way to use the E-Wallet application is difficult to understand if there are application updates that are carried out regularly by the E-Wallet service provider.

\section{The Effect of Perceived Usefulness on Behavioral Intention}

The results show that perceived usefulness does not have a positive and significant effect on interest in using E-Wallet. The results of this study support previous studies that show that perceived usefulness does not directly affect the user's usage habits. (Chawla and Joshi 2019) \& (Sharma et al. 2018) explained the results of the study they obtained regarding the effect of perceived usefulness on behavioral intention, which has insignificant results. One of the factors that might be the reason is that users do not think perceived usefulness affects their sense of trust in using E-Wallet products. Usefulness can function as a benchmark for the number and variety of applications used so that the implications of this condition lead to many user preferences in trying similar E-Wallet applications (Setiani, 2018). On the other hand, the results of this study contradict some previous studies (Aksami dan Jember, 2019); (Routray et al. 2019) \& (Kumala, Pranata, and Thio 2020), which showed that the usefulness aspect has a positive and significant effect on interest in using E-Wallet services. This means that if the usefulness obtained is high, the interest in using E-Wallet services will increase, thus increasing non-cash financial transactions (Kevin Anarjia 2018).

The Effect of Social Influence on Behavioral Intention

The results show that social influence has a positive and significant effect on interest in using EWallet. The social influence of the environment, such as friends and relatives, is one of the factors that drive the use of E-Wallet. As stated by Kim et al. (2016), social influence can affect an individual's behavior change pattern by looking at the internalization and identification of compliance as a form of change in their belief and social status. These findings are also supported by results of the study by (Xu et al. 2017), which explained that the social influence facilitates consumers to carry out financial activities to make it easier due to the more accurate information they obtain from the social environment factors through suggestion and advice from reliable information sources. This supports previous studies conducted by (Sharma et al. 2018) \& (Singh, Sinha, and Liébana- 
Cabanillas 2020), which stated that compared to advertisements, good experiences expressed by close people are more influential in E-Wallet adoption. In the context of Mobile Suica in Japan, social influence also has an important role in the adoption of electronic wallets (Amoroso and MagnierWatanabe 2012). Besides, social influence had been found to be a crucial factor in predicting behavioral intention to implement a solution for the digital wallet in India (Madan and Yadav 2016).

The Effect facility Condition on Behavioral Intention

The results show that the facility condition has a positive and significant effect on the interest in using E-Wallet. The facility condition is defined as beliefs about accessibility to the resources required to facilitate any service (H. W. Kim, Chan, and Gupta 2007). Supporting facilities are one of the factors that are considered important in E-Wallet adoption. Without supporting facilities, it would be difficult to adopt new technologies, such as E-Wallet. In this study, the facility condition is hypothesized to affect the intensity of interest in using E-Wallet. Based on the results of the significance test, it shows that facility condition has a significant and positive effect on behavioral intention. This is similar to the results of the studies by (Chawla \& Joshi 2019) \& (Madan \& Yadav 2016), which stated that the facility condition not only affects perceived usefulness but also on habits or interest in use. Further, a study by (Amoroso and Magnier-Watanabe 2012) stated that the growth of mobile commerce using non-cash payment services could grow rapidly inclusively due to the features provided that make it easy for users.

\section{CONCLUSION AND FURTHER RESEARCH}

Based on the results of hypothesis testing, the conclusions in this study are:

1. The results of testing the perceived ease of use variable show that the ease of use factor has a positive and significant effect on behavioral intention.

2. The results of testing the perceived usefulness variable show that the usefulness factor does not have a positive and significant effect on behavioral intention.

3. The results of testing the social influence variable show that the social factor has a positive and significant effect on behavioral intention.

4. The results of testing the facility condition variable show that the facility factor has a positive and significant effect on behavioral intention.

\section{Further Research}

This study has limitations and suggestions that may affect the results of this study, including:

1. This study is only limited to Generation $Z$ respondents with a total of 146 respondents in Pematangsiantar City so that it is still too small compared to the number of Generation $Z$ using E-Wallet in Indonesia. Therefore, this study has not been able to clearly describe the differences in using E-Wallet. For further research, it is suggested to increase the number of samples and select another research location or place so that the scope of the research can be wider.

2. In this study, the researchers only examined four independent variables, including perceived usefulness, perceived ease of use, social influence, and facility condition, so that they could not cover and determine all the variables that affect the behavior of Generation $\mathrm{Z}$ in using E-Wallet.

3. For further research, regarding the adoption of E-Wallet, it is expected that further researchers can develop and explore issues related to previous research variables, or can also add other 
variables that are related and have not been used in this study, for example, the risk perception, safety factor, technology innovation, trustworthiness, and promotional appeal.

\section{REFERENCES}

Abrahão, Ricardo de Sena, Stella Naomi Moriguchi, and Darly Fernando Andrade. 2016. "Intention of Adoption of Mobile Payment: An Analysis in the Light of the Unified Theory of Acceptance and Use of Technology (UTAUT).” RAI Revista de Administração e Inovação 13(3): 221-30.

Aksami, Ni Made Dwi, Jember, I Made. (2019). Analisis Minat Penggunaan Layanan E-Money Pada Masyarakat Kota Denpasar. E-Jurnal Ekonomi Pembangunan Unversitas Udayana. 8 (9), 67-78.

Alalwan, Ali Abdallah, Yogesh K. Dwivedi, and Nripendra P. Rana. 2017. "Factors Influencing Adoption of Mobile Banking by Jordanian Bank Customers: Extending UTAUT2 with Trust." International Journal of Information Management 37(3): 99-110. http://dx.doi.org/10.1016/j.ijinfomgt.2017.01.002.

Alalwan, Ali Abdallah, Yogesh K. Dwivedi, and Michael D. Williams. 2016. "Customers' Intention and Adoption of Telebanking in Jordan." Information Systems Management 33(2): 154-78.

Alsamydai, Mahmood Jasim et al. 2014. "Www.Tjprc.Org The Factors Influencing Customer Usage Of Mobile Banking Services In Jordan." International Journal of Business Management \& Research 4(2): 2249-6920.

Amoroso, Donald L., and Rémy Magnier-Watanabe. 2012. "Building a Research Model for Mobile Wallet Consumer Adoption: The Case of Mobile Suica in Japan." Journal of Theoretical and Applied Electronic Commerce Research 7(1): 94-110.

Badri, Muhammad. 2020. "InovbizAdopsi Inovasi Aplikasi Dompet Digital Di Kota Pekanbaru." Inovbiz: Jurnal Inovasi Bisnis 8(1): 120-27.

Bagla, Ramesh Kumar, and Vivek Sancheti. 2018. "Gaps in Customer Satisfaction with Digital Wallets: Challenge for Sustainability." Journal of Management Development 37(6): 442-51.

Bank Indonesia. (2019). List Of Electronic Money Operators Licensed By Bank Indonesia - Bank Sentral Republik Indonesia. Payment System License Information, pp. 1-6. Retrieved from https://www.bi.go.id/en/sistemelektronik/penyelenggara- berizin/Pages/default.aspx

Beheshti, Amin, Boualem Benatallah, and Hamid Reza Motahari-Nezhad. 2018. "ProcessAtlas: A Scalable and Extensible Platform for Business Process Analytics." Software - Practice and Experience: 1-25.

Chawla, Deepak, and Himanshu Joshi. 2019. "Consumer Attitude and Intention to Adopt Mobile Wallet in India - An Empirical Study.” International Journal of Bank Marketing 37(7): 1590 1618.

Chin, W. W. (1998). The partial least squares approach to structural equation modelling. In Marcoulides G. A. (Ed.). Modern Methods for Business Research, 295(2), 295-336.

Chen, Q., Chen, H. M., \& Kazman, R. (2007). Investigating antecedents of technology acceptance of initial eCRM users beyond generation $\mathrm{X}$ and the role of self-construal. Electronic Commerce Research, 7(3-4), 315-339. https://doi.org/10.1007/s10660-007-9009-2

Chuang, L. M., Chun, C. L., \& Hsiao, K. K. (2016). The adoption of fintech service: TAM perspective. International Journal of Management and Administrative Sciences, 3, 1-15.

Fitria, Linda, and Adi Winata. 2020. "The Effect of Electronic Coupon Value to Perceived Usefulness and Perceived Ease-of-Use and Its Implication to Behavioral Intention to Use ServerBased Electronic Money." International Journal of Innovative Science and Research Technology 5(1): 147-58.

Gu, Ja Chul, Sang Chul Lee, and Yung Ho Suh. 2009. "Determinants of Behavioral Intention to Mobile Banking." Expert Systems with Applications 36(9): 11605-16. http://dx.doi.org/10.1016/j.eswa.2009.03.024. 
Proceeding on International Conference of Science Management Art Research Technology (IC-SMART),

Vol. 1 (1), 101-116

Constituents Driving Interest in Using E-Wallets in Generation Z

Fitria Halim, Efendi, Marisi Butarbutar, Anne Rumondang Malau, Acai Sudirman

Hair, J. F. et al. 2014. Multivariat Data Analysis 7th Edition. New Jersey: Pearson Prentice Hall. Houston, Dian Dinata. 2020. “Adopsi Penerimaan Digital Payment Pada Kalangan Milenial." Medium 7(2): 55-67.

Howe,N.,\&Nadler,R.(2012).WhyGenerationsMatter :TenFindings from LifeCourse Research on the Workforce.

Huei, Cham Tat et al. 2018. "Preliminary Study on Consumer Attitude towards Fintech Products and Services in Malaysia." International Journal of Engineering and Technology(UAE) 7(2): 166-69.

Intarot, Pharot, and Chutima Beokhaimook Beokhaimook. 2018. "Influencing Factor in E-Wallet Acceptant and Use." International Journal of Business and Administrative Studies 4(4): 167-75.

Juliandi, A. (2018). Membangun Model PLS di SmartPLS. 16-17. https://doi.org/10.5281/zenodo.2538001

Keng-Soon, Chong et al. 2019. "An Adoption of Fintech Service in Malaysia." South East Asia Journal of Contemporary Business, Economics and Law 18(5): 73-92.

Kesumastuti, Teresia Miranti. 2020. "The Process of Adoption Interest in Using Digital Wallet in Central Jakarta ( Case Study on Go-Pay Users )." International Journal of Multicultural and $\begin{array}{lll}\text { Multireligious } & \text { Understanding } & \text { 277-86. }\end{array}$ https://ijmmu.com/index.php/ijmmu/article/download/1463/1159.

Kevin Anarjia, Jones Z. Rante. 2018. "Pengaruh Persepsi Manfaat Dan Persepsi Kemudahan Penggunaan Terhadap Minat Menggunakan Layanan Uang Elektronik Sakuku Pt. Bank Central Asia, Tbk Kcu Cikarang." Jurnal SISTEM INFORMASI 1(2): 1-7.

Kim, Changsu, Wen Li, and Dan J. Kim. 2015. "An Empirical Analysis of Factors Influencing MShopping Use.” International Journal of Human-Computer Interaction 31(12): 974-94.

Kim, Y., Choi, J., Park, Y., \& Yeon, J. (2016). The adoption of mobile payment services for "Fintech". International Journal of Applied Engineering Research, 11(2), 1058-1061.

Kim, Hee Woong, Hock Chuan Chan, and Sumeet Gupta. 2007. "Value-Based Adoption of Mobile Internet: An Empirical Investigation.” Decision Support Systems 43(1): 111-26.

Kumala, Debby Cynthia, Joshua Wilson Pranata, and Sienny Thio. 2020. "Pengaruh Perceived Usefulness, Perceived Ease of Use, Trust, Dan Security Terhadap Minat Penggunaan Gopay Pada Generasi X Di Surabaya." Jurnal Manajemen Perhotelan 6(1): 19-29.

Kumar, Anup, Amit Adlakaha, and Kampan Mukherjee. 2018. "The Effect of Perceived Security and Grievance Redressal on Continuance Intention to Use M-Wallets in a Developing Country." International Journal of Bank Marketing 36(7): 1170-89.

Lancelot Miltgen, Caroline, Aleš Popovič, and Tiago Oliveira. 2013. "Determinants of End-User Acceptance of Biometrics: Integrating the 'Big 3' of Technology Acceptance with Privacy Context.” Decision Support Systems 56(1): 103-14.

Lavenia, Binti Clara, Mohammad Iqbal, and Ari Irawan. 2018. "Pengaruh Technology Acceptance Model (Tam) Dan Electronic Word Of Mouth (Ewom) Terhadap Kepuasan Pelanggan (Survei Pada Pelanggan Go-Jek Di Kota Kediri)." Jurnal Administrasi Bisnis 60(3): 52-61.

Lu, J., Yao, J. E., \& Yu, C. S. (2005). Personal innovativeness, social influences and adoption of wireless Internet services via mobile technology. Journal of Strategic Information Systems, 14(3), 245-268. https://doi.org/10.1016/j.jsis.2005.07.003

Madan, Khushbu, and Rajan Yadav. 2016. "Behavioural Intention to Adopt Mobile Wallet: A Developing Country Perspective." Journal of Indian Business Research 8(3): 227-44.

Mehra, Aashish, Justin Paul, and Rahul Pratap Singh Kaurav. 2020. "Determinants of Mobile Apps Adoption among Young Adults: Theoretical Extension and Analysis." Journal of Marketing Communications 00(00): 1-29. https://doi.org/10.1080/13527266.2020.1725780.

Moslehpour, Massoud, Van Kien Pham, Wing Keung Wong, and Ismail Bilgiçli. 2018. "E-Purchase Intention of Taiwanese Consumers: Sustainable Mediation of Perceived Usefulness and Perceived Ease of Use." Sustainability (Switzerland) 10(1).

Nidhi singh, Shalini Srivastava, Neena Sinha. 2017. "Consumer Preference and Satisfaction of MWallets: A Study on North Indian Consumers." International Journal of Bank Marketing 12(7): $1-32$. 
Purwanto, Sugeng, Sri Hartini, and Gancar Candra Premananto. 2019. "Understanding Consumer Intention to Use Go-Pay: Development and Testing of Technology Acceptance Models for Consumers." Eksis 14(1).

Rif'ah, Sifwatir Rif'ah. 2019. "Fenomena Cashless Society Di Era Milenial Dalam Perspektif Islam." Al-Musthofa: Journal of Sharia Economics 2(February): 1-9.

Routray, Susmi, Reema Khurana, Ruchi Payal, and Rakesh Gupta. 2019. "A Move towards Cashless Economy: A Case of Continuous Usage of Mobile Wallets in India." Theoretical Economics Letters 09(04): 1152-66.

Samudra, M. S., \& Phadtare, M. (2012). Factors Influencing The Adoption Of Mobile Banking With Special Reference To Pune City. Asci Journal Of Management , 42 (1), 5165.

Sharma, Sujeet Kumar, Sachin Kumar Mangla, Sunil Luthra, and Zahran Al-Salti. 2018. "Mobile Wallet Inhibitors: Developing a Comprehensive Theory Using an Integrated Model." Journal of Retailing and Consumer Services 45(June): 52-63. https://doi.org/10.1016/j.jretconser.2018.08.008.

Salmony, M. (2014). Access to accounts: why banks should embrace an open future. Journal of Payments Strategy \& Systems, 8(2), 169-170.

Sarwono J. 2016. Membuat Skripsi, Tesis dan Disertasi dengan Partial Least Square SEM (PLS SEM). Yogyakarta. Penerbit Andi.

Setiani, Rahayu. (2018). Faktor- Faktor Yang Mempengaruhi Penggunaan Alat Pembayaran Non Tunai (Studi di Kota Purbalingga). Yogyakarta: Unviersitas Islam Indonesia. Skripsi.

Singh, Nidhi, Neena Sinha, and Francisco J. Liébana-Cabanillas. 2020. "Determining Factors in the Adoption and Recommendation of Mobile Wallet Services in India: Analysis of the Effect of Innovativeness, Stress to Use and Social Influence." International Journal of Information Management 50(October 2018): 191-205. https://doi.org/10.1016/j.ijinfomgt.2019.05.022.

Sunny, Prajod. 2018. "Determinants of Behavioral Intention To Use Mobile Wallets--a Conceptual Model." Journal of Management (JOM) 5(5): 52-62.

Venkatesh, Viswanath, G. Morris, Michael, Gordon B. Davis, and Fred D. Davis. 2016. "USER ACCEPTANCE OF INFORMATION TECHNOLOGY: TOWARD A UNIFIED VIEW." Inorganic Chemistry Communications 67(3): 95-98.

Welly, Yerisma, Supitriyani, Yusnaini, and Acai Sudirman. 2020. "Factors of Using Non-Cash Payments to the Consumption Level of Students." 7(1): 61-68.

Wong, Wai Han, and Wing Ying Mo. 2019. "A Study of Consumer Intention of Mobile Payment in Hong Kong, Based on Perceived Risk, Perceived Trust, Perceived Security and Technological Acceptance Model.” Journal of Advanced Management Science 7(2): 33-38.

Wonglimpiyarat, Jarunee Wonglimpiyarat. 2017. "FinTech Banking Industry: A Systemic Approach." Foresight 19(6): 590-603.

$\mathrm{Xu}$, Xiaoyu et al. 2017. "The Impact of Informational Incentives and Social Influence on Consumer Behavior during Alibaba's Online Shopping Carnival." Computers in Human Behavior 76: 24554. 